\title{
Seasonal Changes in a Sandy Beach Fish Assemblage at Canto Grande, Santa Catarina, South Brazil
}

\author{
João P. Barreiros $\dagger^{*}$, Vicente Figna $\ddagger$, Maurício Hostim-Silva $\ddagger$ and Ricardo S. Santos $\S$ \\ †Universidade dos Açores \\ Departamento de Ciências \\ Agrárias \\ 9701-851 Angra do Heroísmo, \\ Portugal \\ jpedro@angra.uac.pt \\ \$Universidade do Vale do \\ Itajaí \\ Centro de Ciências \\ Tecnológicas da Terra e do \\ Mar \\ CP 360 \\ 88032-202 Itajaí, SC, Brazil \\ §Universidade dos Açores \\ Departamento de \\ Oceanografia e Pescas \\ 9901-862 Horta, Portugal
}

\begin{abstract}
BARREIROS, J.P.; FIGNA, V.; HOSTIM-SILVA, M., and SANTOS, R.S., 2004. Seasonal changes in a sandy beach fish assemblage at Canto Grande, Santa Catarina, South Brazil. Journal of Coastal Research, 20(3), 862-870. West Palm Beach (Florida), ISSN 0749-0208.

A shallow-water fish assemblage, over a soft, sandy bottom, at Canto Grande, Santa Catarina, Brazil, was sampled with a beach seine. Sampling was undertaken at $3 \mathrm{~h}$ intervals over $24 \mathrm{~h}$ on a bimonthly basis between April 1996 and February 1997. There was a seasonal variation in the number of species, density of fishes and biomass with the highest values in February (38 species, 257.6 fish $1000 \mathrm{~m}^{-2}, 2286.4 \mathrm{~g} 1000 \mathrm{~m}^{-2}$ ). A total of 67 species, belonging to 56 genera and 33 families were collected and the assemblage was dominated by seven species belonging to three families: Atherinella brasiliensis (Atherinidae); Brevoortia pectinata, Harengula clupeola and Sardinella brasiliensis (Clupeidae); Anchoviella lepidontostole, Cetengraulis edentulus and Lycengraulis grossidens (Engraulidae). Species diversity $\left(H^{\prime}\right)$ and equitability $\left(J^{\prime}\right)$ were medium to high throughout the year due to the low dominance. The largest change in the assemblage structure occurred between winter months (July and August) and the other seasons. None of the dominant species can be classified as a resident. Main predators were Pomatomus saltator (winter) and Trichiurus lepturus (summer). Most of the species observed were either juvenile fish or small pelagic and strongly gregarious species.
\end{abstract}

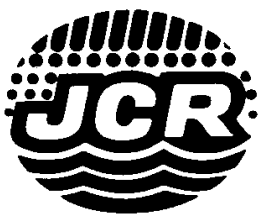

ADDITIONAL INDEX WORDS: Fish assemblage, seasonal variations, sandy beach, Santa Catarina, south Brazil.

\section{INTRODUCTION}

Seasonal variations of fish assemblages in shallow-water sandy beaches have been studied by several authors, mainly in the Atlantic and Indian Oceans (e.g. NASH, 1988; WRIGHT, 1988; Ali and Hussain, 1990; SANTOS and NASH, 1995; NASH and SANTOS, 1998; LAZZARI et al., 1999). The general ecology of sandy beaches was thoroughly and comprehensively described by Brown and McLACHLAN (1990). According to BEYsT et al. (2001) temporal variation of epibenthic surfzone fish fauna is well documented. However, the factors that influence or control these variations are still unclear (CLARK et al., 1996). Fish aggregations in sandy beaches include a high richness in species (between 27 and 71). Some of these are numerically dominant due to the fact that they occur in large schools (BROWN and McLACHLAN, 1990). Biomass structure, however, tends to be more equilibrated since solitary species generally occur as adult, bigger individuals. Nevertheless, seasonal and annual fluctuations in species richness and composition seem to be typical of fish communities of sandy beaches (e.g. Brown and McLACHLAN, 1990; HoOK, 1991).

01116 re-received and accepted in revision 5 April 2003.
Shallow water areas are known to constitute important feeding and nursery grounds for many fish species (MCERlean et al., 1973; Bennett, 1989; Brown and MACLACHLAN, 1990; SANTOS et al., 1994) and have been studied in several places (e.g. SANTOS and NASH, 1995; VARGAS and Sielfeld, 1997; AraúJo and Costa de Azevedo, 2001).

The southern Brazilian State of Santa Catarina has many sandy beaches interspersed with rocky shores. Beaches are either sheltered or exposed but are generally heavily exploited by tourism, urbanisation and shellfish farming. The fish communities of Santa Catarina's sandy beaches were never described or analysed in their multiple components. Our objectives were: i) to describe the fish community of this particular sandy beach, since it is characteristic of Santa Catarina's littoral and may be important as a nursery and feeding ground for an important group of species; ii) analyse temporal variations in the community and the influence of main abiotic factors such as temperature and salinity, which are known to be important regulating factors in fish assemblages from sandy beaches (LAZZARI et al., 1999).

This study provides a description of the seasonal fluctuations in a shallow-water, sandy beach fish assemblage, comparing this with other studies undertaken elsewhere in the Atlantic Ocean. 


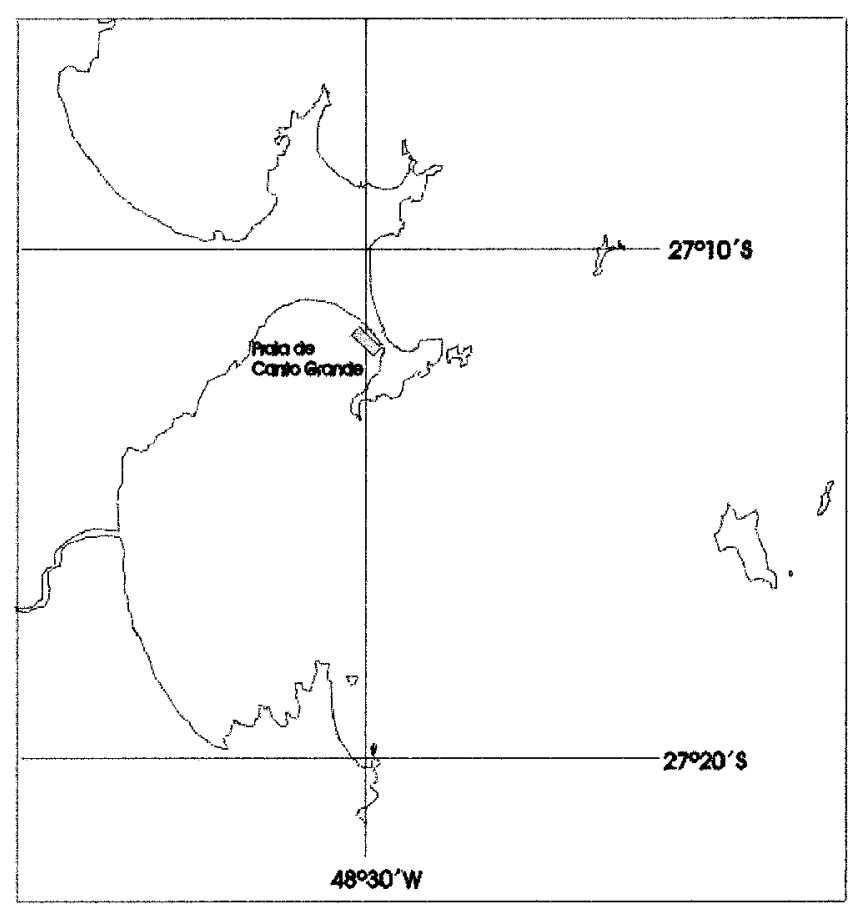

Figure 1. The beach of Canto Grande, Santa Catarina, Brazil.

\section{METHODS}

\section{Study Site}

Santa Catarina has a $390 \mathrm{~km}$ long shoreline which is characterized by many sheltered bays with sandy beaches interspersed with rocky formations. Several rivers outflow to the shores, thus creating important estuaries and mangrove forests. Tourism and shellfish culture are widespread industries and greatly modified substantial parts of the littoral. This study was carried out in Canto Grande beach (CG) (Figure 1). This is a $600 \mathrm{~m}$ long sandy beach, sheltered and intensively used by tourism and for shellfish culture (Perna perna, Ostrea puelchana and Crassostrea rizophorae), and has the most important human settlement of the area. The beach is located at the southernmost tip of the Bombinhas peninsula $\left(27^{\circ} 08^{\prime} \mathrm{S}, 48^{\circ} 30^{\prime} \mathrm{W}\right)$, facing south, approximately $30 \mathrm{~km}$ north of Santa Catarina island and is representative of Santa Catarina's seashore. Canto Grande beach is formed by fine grain sand and important deposits of shellfish. Both east and west borders of the beach are rocky. The maximum tidal range is $1 \mathrm{~m}$ and maximum depth is $3 \mathrm{~m}$. Although there is a substantial lack of data on pollution and eutrophication of Santa Catarina's shores, it is known that metals $(\mathrm{Cu}, \mathrm{Cr}$ and $\mathrm{Zn}$ ) are found in Canto Grande's mussels as a result of the increase of human settlement. These values are, however, below the legal limits (ROQUE and KuROshima, 2000).

\section{Collection of Data}

Sampling was undertaken with a $30 \mathrm{~m}$ beach seine, $2 \mathrm{~m}$ high in the tips and $3 \mathrm{~m}$ high in the middle. The mesh is 10 $\mathrm{mm}$. The beach seine was fitted with $50 \mathrm{~m}$ hauling ropes and set parallel to the shore. Each haul had an effective fishing area between $3 \mathrm{~m}$ depth and the shore, allowing for efficiency at the wings of about $1036 \mathrm{~m}^{2}$ (according to the calculation method of KUBECKA and BoHM, 1991). Three hauls $\left(3108 \mathrm{~m}^{2}\right)$ of the beach seine were made at $3 \mathrm{~h}$ intervals for $24 \mathrm{~h}$ on each sampling date, coinciding with high, mid-falling, low and mid-rising tide (diel and tidal changes in the fish community will be treated elsewhere-BARREIRos et al., in prep.). Seasurface temperature and salinity were measured during all sampling dates, immediately before each collection.

The total number of individuals and total weight for each species was recorded. The total lengths (to the nearest $\mathrm{mm}$ ) and individual wet weights (to the nearest g) (using a subsample of up to 200 individuals when necessary) were recorded for each sample. The three samples at each sampling time were summed to give one total following the methodology used by SANTOS and NASH (1995). Average catches were calculated as the number and grams ( $\mathrm{g}$ ) of fish $1000 \mathrm{~m}^{-2}$.

Species diversity was measured from the number of species and the Shannon diversity index $\left(H^{\prime}\right)$ (LUDwIG and REYNOLDS, 1988):

$$
\mathrm{H}^{\prime}=-\sum_{\mathrm{i}=1}^{\mathrm{s}}(\mathrm{pi} \log \mathrm{epi})
$$

in which

$\mathrm{Pi}=\mathrm{n}_{\mathrm{i}} / \mathrm{N}$ (the proportional abundance of the ienth species), $\mathrm{n}_{\mathrm{i}}=$ total number of individuals in the ienth species, and $\mathrm{N}=$ Total number of individuals from all species.

The impact of dominant species was analysed with the Berger-Parker index (d) (BERGER and PARKER, 1970):

$$
\mathrm{d}=\mathrm{n}_{\max } / \mathrm{N},
$$

in which

$\mathrm{n}_{\max }=$ total number of individuals from the most abundant species and

$\mathrm{N}=$ total number of individuals from all species.

Inverse dominance (1/d) was calculated for it allows better interpretation of the Berger-Parker index.

Equitability between species was measured with Pielou's evenness function $\left(J^{\prime}\right)$ (PIELOU, 1977):

$$
\mathrm{J}^{\prime}=\mathrm{H}^{\prime} / \log _{\mathrm{e}}(\mathbf{S}),
$$

in which

$H^{\prime}=$ Shannon's diversity index and

$\mathrm{S}=$ total number of species.

Differences over the year between biomass, number of individuals, $\left(H^{\prime}\right)$ and $\left(J^{\prime}\right)$ were tested with paired t-tests.

The percent similarity between successive months was calculated using the Jaccard Coefficient $\left(\mathrm{C}_{J}\right)$ by comparing pairs of samples based on the presence and number of species in each sample (MAGURRAN, 1988):

$$
C_{J}=j /(a+b-j)
$$

in which, 
$\mathrm{j}=$ number of species from both samples,

$\mathrm{a}=$ number of species from sample $\mathrm{A}$ and

$\mathrm{b}=$ number of species from sample B.

All ecological analyses were performed using the software Biodiversity Professional ${ }^{\circledR}$ v. 1997. All statistics (t-tests and Spearman rank correlations) were performed using Statisti$\mathrm{ca}^{\circledR}$ for Windows ${ }^{\circledR}$, vs. 3.0.

\section{RESULTS}

\section{Sea-Surface Temperature}

Over the sampling period temperatures varied between $16.3^{\circ} \mathrm{C}$ (July) and $26.2^{\circ} \mathrm{C}$ (December), which correspond to the averages verified in the northern part of Santa Catarina (SEGE, 1991).

\section{Salinity}

Salinity varied between a minimum of 27.4 (February) and a maximum of 33.8 (December). Intense rains and river outflow are interpreted as the cause for a drop in salinity verified in February.

\section{Fish Assemblage}

Sixty-seven species were caught yielding 9370 fish or $77943.55 \mathrm{~g}$ (Table 1 ). This constitutes a yearly average of 62.8 fish $1000 \mathrm{~m}^{-2}$ or $522 \mathrm{~g} 1000 \mathrm{~m}^{-2}$. Over the sampling periods, estimated density was highest in February (257.6 fish 1000 $\mathrm{m}^{-2}$ ) and lowest in December (60.9 fish $1000 \mathrm{~m}^{-2}$ ). Biomass followed the same pattern with a maximum in February

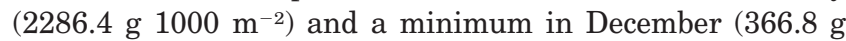
$1000 \mathrm{~m}^{-2}$ ).

The fish assemblage of CG was numerically dominated by Lycengraulis grossidens (21.5\%), Harengula clupeola (11.6\%) and Atherinella brasiliensis (11.1\%). In terms of biomass, the most important species were Trichiurus lepturus (13.2\%), Brevoortia pectinata (12.4\%) and Hemiramphus brasiliensis (10.0\%). Seven species, belonging to three families, corresponded to $70.4 \%$ of the number of fish caught: Atherinella brasiliensis (Atherinidae-11.1\%); Brevoortia pectinata, Harengula clupeola and Sardinella brasiliensis (Clupeidae26.4\%); Anchoviella lepidontostole, Cetengraulis edentulus and Lycengraulis grossidens (32.9\%). Most speciose families were: Carangidae (9 species), Sciaenidae (6) and Clupeidae (5).

Of the species caught only five can be considered as typical residents of sandy bottoms: Mullus argentinae and Pseudupeneus maculatus (Mullidae), Citharichthys spilopterus (Paralichthyidae) and Synodus foetens (Synodontidae). However, they occurred in very low numbers as these are bottom-dwelling species, and the sampling method was inadequate for such a category (see discussion).

As to biomass, nine species, belonging to six families, corresponded to $68.9 \%$ of all biomass obtained: A. brasiliensis (Atherinidae), B. pectinata, H. clupeola, S. brasiliensis (Clupeidae), L. grossidens (Engraulidae), Hemiramphus brasiliensis (Hemiramphidae), Pomatomus saltatrix (Pomatomidae), Isopisthus parvipinnis (Sciaenidae) and Trichiurus lepturus (Trichiuridae). Both density and average biomass of these most important species were low (Tables 2 and 3).

\section{Number of Species}

With the exception of the correlation with salinity (see below), no clear pattern in the number of species caught at CG was visible. February, with 38 species was the maximum and December, with 21, the minimum. In the other months, the number of species varied between 29 and 36 . There was a negative and significant correlation between salinity and the number of species $\left(\mathrm{r}_{\mathrm{s}}=-0.890, \mathrm{p}<0.05\right)$ (Figure 2).

\section{Density and Biomass}

The same pattern was observed for both density and biomass. Total number of individuals and total biomass was highest in February and lowest in December. Maximum density occurred just after the lowest value of December and just after the maximum temperature and salinity (Figure 3). However, the correlation between them was not significant. Biomass was negatively correlated with salinity $\left(\mathrm{r}_{\mathrm{s}}=-0.820\right.$, $\mathrm{p}<0.05$ ) (Figure 4), and its February peak was due to high catches of Trichiurus lepturus during that period.

Although there were no significant differences $(p>0.05)$ between densities over the year, differences in biomass were significant (Table 4) in winter and spring months.

\section{Seasonal Occurrence of Fish Species}

Nine species were particularly important in the CG community and had a major influence in the total number of individuals occurring in each sample. April was dominated by Atherinella brasiliensis with an importance of $34.7 \%$ of the total. In July, the community was thoroughly dominated by Lycengraulis grossidens (40.5\%) but with an isolated influx of the predator Pomatomus saltator (20.0\%). August was dominated by Harengula clupeola (33.0\%) and by Lycengraulis grossidens (26.6\%) while October was dominated by Brevoortia pectinata $(36.5 \%)$. Three species dominated the community in December: L. grossidens (18.5\%), Eucinostomus argenteus $(17.7 \%)$ and H. clupeola (17.6\%). In February, newcomers such as Cetengraulis edentulus (21.7\%) and Anchoviella lepidontostole (15.3\%) and increased catches of Sardinella brasiliensis $(19.2 \%)$ characterised the community. The only dominant species to occur in every month was $L$. grossidens.

Two species showed a significant correlation with temperature: $S$. brasiliensis $\left(\mathrm{r}_{\mathrm{s}}=0.829, \mathrm{p}<0.05\right)$ and Trichiurus lepturus $\left(\mathrm{r}_{\mathrm{s}}=0.928, \mathrm{p}<0.01\right)$. No significant correlation was observed between any species and salinity.

\section{Species Diversity $\left(H^{\prime}\right)$ and Evenness $\left(J^{\prime}\right)$}

Diversity showed a positive correlation with sea-surface temperature $\left(\mathrm{r}_{\mathrm{s}}=0.943, \mathrm{p}<0.01\right)$ (Figure 5). Highest diversity coincided with maximum values of temperature and salinity. This parameter was not correlated with the number of individuals. The low values of $H^{\prime}$ during the winter months (July and August) are due to low richness and to high dominance respectively from one to two species. This is also shown by the Berger-Parker analysis (Table 5) in which the abundance of the dominant species is clearly higher in winter months. The peak of December reflects an increase in the number of dominant species and the February decrease is 
Table 1. Biomass and number of specimens caught at Canto Grande, SC, Brazil (in alphabetical order of families).

\begin{tabular}{|c|c|c|c|c|c|}
\hline Family & Species & Biomass (g) & $\begin{array}{c}\text { Percentual } \\
\text { Importance } \\
\text { (biomass) }\end{array}$ & $\begin{array}{l}\text { Number of } \\
\text { Specimens }\end{array}$ & $\begin{array}{c}\text { Percentual } \\
\text { Importance } \\
\text { (numeric) }\end{array}$ \\
\hline Albulidae & Albula vulpes & 108.58 & 0.1 & 38 & 0.4 \\
\hline \multirow{2}{*}{ Atherinidae } & Atherinella brasiliensis & 5289.02 & 6.8 & 1041 & 11.1 \\
\hline & Odontesthes bonariensis & 250,54 & 0.3 & 42 & 0.5 \\
\hline \multirow[t]{2}{*}{ Belonidae } & Strongylura marina & 231,87 & 0.3 & 6 & $*$ \\
\hline & Strongylura timucu & 6.36 & $*$ & 2 & * \\
\hline Blennidae & Hypleurochilus fissicornis & 6.41 & $*$ & 1 & * \\
\hline \multirow[t]{9}{*}{ Carangidae } & Caranx latus & 88.8 & 0.1 & 6 & * \\
\hline & Chloroscombrus chrysurus & 2.3 & $*$ & 1 & * \\
\hline & Hemicaranx amblyrhynchus & 2.91 & * & 5 & $*$ \\
\hline & Hemicaranx sp. & 42.41 & $*$ & 1 & $*$ \\
\hline & Oligoplites palometa & 1.62 & * & 1 & * \\
\hline & Oligoplites saurus & 447.38 & 0.6 & 49 & 0.5 \\
\hline & Selene vomer & 325.33 & 0.4 & 5 & \\
\hline & Trachinotus carolinus & 886.4 & 1.1 & 163 & 1.7 \\
\hline & Trachinotus falcatus & 700.08 & 0.9 & 179 & 1.9 \\
\hline Chaetodontidae & Chaetodon ocellatus & 1.96 & $*$ & 1 & * \\
\hline \multirow[t]{5}{*}{ Clupeidae } & Brevoortia pectinata & 9691.96 & 12.4 & 688 & 7.3 \\
\hline & Harengula clupeola & 4443.85 & 5.7 & 1086 & 11.6 \\
\hline & Opisthonema oglinum & 1107.97 & 1.4 & 233 & 2.5 \\
\hline & Pellona harroweri & 156.55 & 0.2 & 5 & * \\
\hline & Sardinella brasiliensis & 4038.70 & 5.2 & 705 & 7.5 \\
\hline Dactylopteridae & Dactylopterus volitans & 415.17 & 0.5 & 1 & * \\
\hline Diodontidae & Chilomycterus altringa & 714.07 & 0.9 & 25 & 0.3 \\
\hline \multirow[t]{3}{*}{ Engraulidae } & Anchoviella lepidontostole & 919.11 & 1.2 & 442 & 4.7 \\
\hline & Cetengraulis edentulus & 1403.25 & 1.3 & 625 & 6.7 \\
\hline & Lycengraulis grossidens & 3703.77 & 4.8 & 2012 & 21.5 \\
\hline Ephippidae & Chaetodipterus faber & 1.46 & $*$ & 1 & * \\
\hline Exocoetidae & Exocoetus volitans & 3.56 & * & 1 & * \\
\hline \multirow[t]{2}{*}{ Fistularidae } & Fistularia petimba & 23.69 & * & 4 & $*$ \\
\hline & Fistularia tabacaria & 2.86 & * & 1 & * \\
\hline \multirow[t]{4}{*}{ Gerreidae } & Diapterus rhombeus & 56.85 & * & 15 & 0.2 \\
\hline & Eucinostomus argenteus & 1552.32 & 2.0 & 345 & 3.7 \\
\hline & Eucinostomus gula & 1581.59 & 2.0 & 101 & 1.1 \\
\hline & Eucinostomus melanopterus & 1840.78 & 2.4 & 124 & 1.3 \\
\hline Gobiesocidae & Gobiesox strumosus & 14.15 & $*$ & 2 & $*$ \\
\hline \multirow[t]{3}{*}{ Haemulidae } & Genyatremus luteus & 314.84 & 0.4 & 8 & * \\
\hline & Orthopristis ruber & 1219.56 & 1.6 & 80 & 0.8 \\
\hline & Pomadasys corvinaeformis & 1067.71 & 1.4 & 27 & 0.3 \\
\hline Hemiramphidae & Hemiramphus brasiliensis & 7788.49 & 10.0 & 242 & 2.6 \\
\hline Lutjanidae & Lutjanus synagris & 385.11 & 0.5 & 19 & 0.2 \\
\hline Monacanthidae & Stephanolepis hispidus & 159.51 & 0.2 & 11 & 0.1 \\
\hline \multirow[t]{4}{*}{ Mugilidae } & Mugil curema & 1340.63 & 1.7 & 25 & 0.3 \\
\hline & Mugil gaimardianus & 996.06 & 1.3 & 58 & 0.7 \\
\hline & Mugil platanus & 186.84 & 0.2 & 9 & 0.1 \\
\hline & Mugil sp. & 14.71 & * & 58 & 0.7 \\
\hline \multirow{2}{*}{ Mullidae } & Mullus argentinae & 8.04 & * & 2 & $*$ \\
\hline & Pseudupeneus maculatus & 7.55 & * & 1 & * \\
\hline Paralichthyidae & Citharichthys spilopterus & 138.65 & 0.2 & 46 & 0.5 \\
\hline Pomatomidae & Pomatomus saltator & 3397.25 & 4.4 & 361 & 3.9 \\
\hline \multirow[t]{6}{*}{ Sciaenidae } & Cynoscion leiarchus & 74.61 & $*$ & 1 & * \\
\hline & Isopisthus parvipinnis & 4965.21 & 6.4 & 65 & 0.7 \\
\hline & Menticirrhus americanus & 12.47 & $*$ & 1 & $*$ \\
\hline & Menticirrhus littoralis & 96.55 & 0.1 & 6 & * \\
\hline & Micropogonias furnieri & 23.05 & $*$ & 2 & $*$ \\
\hline & Stellifer rastrifer & 5.13 & * & 9 & 0.1 \\
\hline Scorpaenidae & Scorpaena plumieri & 1.29 & * & 1 & $*$ \\
\hline \multirow[t]{3}{*}{ Serranidae } & Diplectrum radiale & 485.60 & 0.6 & 32 & 0.3 \\
\hline & Epinephelus niveatus & 91.61 & 0.1 & 1 & * \\
\hline & Mycteroperca acutirostris & 53.35 & $*$ & 1 & * \\
\hline Sparidae & Diplodus argenteus & 229.34 & 0.3 & 69 & 0.7 \\
\hline Sphyraenidae & Sphyraena tome & 252.45 & 0.3 & 3 & * \\
\hline Syngnathidae & Bryx dunckeri & 2.22 & $*$ & 1 & $*$ \\
\hline Synodontidae & Synodus foetens & 599.23 & 0.8 & 13 & 0.1 \\
\hline Tetraodontidae & Lagocephalus laevigatus & 2100.47 & 2.7 & 26 & 0.3 \\
\hline & Sphoeroides testudineaus & 1484.39 & 1.9 & 48 & 0.5 \\
\hline Trichiuridae & Trichiurus lepturus & 10265.61 & 13.2 & 159 & 1.7 \\
\hline Triglidae & Prionotus punctatus & 122.12 & 0.2 & 21 & 0.2 \\
\hline Totals & $67 \mathrm{sp}$. & 77943.55 & 100 & 9370 & 100 \\
\hline
\end{tabular}

* Indicates values inferior to $0.1 \%$ 
Table 2. Average density of most important species from Canto Grande, SC, Brazil $n^{\circ}$ fish $100 \mathrm{~m}^{-2}$ ) between April 1996 and February 1997.

\begin{tabular}{|c|c|c|c|c|c|c|}
\hline & April & July & August & October & December & February \\
\hline Lycengraulis grossidens & 0.01 & 0.03 & 0.01 & 0.01 & $*$ & 0.02 \\
\hline Harengula clupeola & $*$ & 0.01 & 0.02 & - & * & $*$ \\
\hline Atherinella brasiliensis & 0.02 & $*$ & 0.01 & $*$ & $*$ & $*$ \\
\hline Sardinella brasiliensis & $*$ & * & $*$ & $*$ & $*$ & 0.02 \\
\hline Brevoortia pectinata & - & - & - & 0.02 & $*$ & $*$ \\
\hline Cetengraulis grossidens & - & - & - & - & - & 0.03 \\
\hline Anchoviella lepidontostole & - & - & - & - & - & 0.02 \\
\hline
\end{tabular}

* Indicates densities lower than 0.01 fish $1000 \mathrm{~m}^{-1}$

due to the large influx of both Sardinella brasiliensis and Cetengraulis edentulus into the community.

Evenness was generally moderately high $(>0.4)$ which reflects the low level of dominance in the assemblage. Equitability was lowest in winter due to a decrease in the number of dominant species, and showed a perfect correlation with temperature $\left(\mathrm{r}_{\mathrm{s}}=1,000\right)$ (Figure 6).

Neither $H^{\prime}$ nor $J^{\prime}$ showed significant differences $(\mathrm{p}>0.05)$ over the year.

\section{Percent Similarity}

Similarity between adjacent samples was always around 50\% (Figure 7). The pairs April/February and October/December clustered more closely than the winter months (July/ August). All months had a different set of species, which explains the low similarities recorded. The large influx of newcomers in February, namely Anchoviella lepidontostole and Cetengraulis edentulus and the increased catches of both Sardinella brasiliensis and Trichiurus lepturus were the main reasons for the differences then recorded.

\section{DISGUSSION}

The fish assemblage in Canto Grande beach is disturbed by human activities, especially in summer with a great increase in the number of visitors. Marine culture of shellfish (oysters and mussels) are a major disruption cause that adds significant quantities of organic matter to the environment and are known to cause a serious impact on the granulometry and physical characteristics of the substrate (ScHETTINI, 1997).

As seen in other similar beaches from the Atlantic (see SANTOs and NASH, 1995), CG undergoes a strong seasonal change in abundance and especially in biomass values. Our sampling strategy, while covering all tidal states and diel cycles, gives us a fairly good descriptor of the community.

Biomass and abundance in CG are inferior to those observed in more tropical regions (see Ross et al., 1987) but remain comparable to more temperate regions. In our site, greatest values of both biomass, abundance and richness are from summer months, as it happens in other temperate regions (e.g. NASH, 1988; Wright, 1988; BennetT, 1989; PESSANHA et al., 1999). This is a known and expected fact-generally, greater abundances and diversity occur in late spring and summer (Brown and MacLachlan, 1990) due to the influx of juveniles of both resident and transient species following their breeding seasons (GIBSON and YoshIYAMA, 1999). On the other hand, the reduction in density and diversity verified in autumn and winter samples is probably a result of offshore migration of fish, as seen in most temperate regions (GIBson, 1999). Although there is no a clear trend, this fish assemblage, being dominated by schools of pelagic species, shows a relatively high level of equitability throughout the year. As considered by SANTOS and NASH (1995) this is just the opposite of what generally occurs in shallow-water areas from temperate to subtropical zones.

The fish assemblage of CG has a high number of species (67). BRown and MACLACHLAN (1990) indicate that sandy beaches usually have between 27 and 71 species. As recorded for other areas, CG seems to have a number of species that is intermediate between colder temperate areas and tropical ones: e.g. 24 species in Scotland (GIBson and EzzI, 1987), 20 species in Cape, South Africa (BEnNETt, 1989), 18 species in Nova Scotia (Black and Miller, 1991), 24 species in the Azores (SANTOS and NASH, 1995) and in a set of Belgian beaches (BEYsT et al., 2001), 75 species in Igarapés, northeastern Brazil (CAstro, 1999), and 80 species in Sepetiba, south-eastern Brazil (PessAnHA et al., 1999). However, as

Table 3. Average biomass of most important species from Canto Grande, SC, Brazil (g $1000 \mathrm{~m}^{-2}$ ) between April 1996 and February 1997.

\begin{tabular}{|c|c|c|c|c|c|c|}
\hline & April & July & August & October & December & February \\
\hline Trichiurus lepturus & 0.07 & - & - & 0.04 & 0.04 & 0.26 \\
\hline Brevoortia pectinata & - & - & - & 0.24 & 0.04 & 0.11 \\
\hline Hemiramphus brasiliensis & 0.04 & 0.17 & 0.07 & $*$ & 0.03 & $*$ \\
\hline Atherinella brasiliensis & 0.09 & 0.03 & 0.07 & 0.02 & $*$ & $*$ \\
\hline Isopisthus parvipinnis & 0.03 & - & - & $*$ & 0.01 & 0.15 \\
\hline Harengula clupeola & $*$ & 0.05 & 0.06 & - & 0.02 & 0.04 \\
\hline Sardinella brasiliensis & 0.01 & $*$ & $*$ & 0.01 & $*$ & 0.14 \\
\hline
\end{tabular}

* Indicates biomass lower than $0.01 \mathrm{~g} 1000 \mathrm{~m}^{-2}$ 


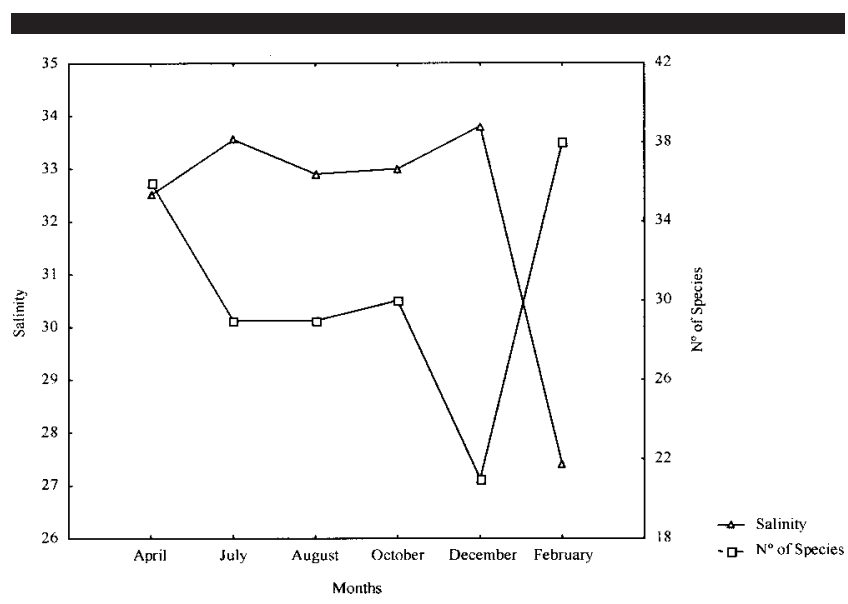

Figure 2. Number of species and salinity in Canto Grande, SC, Brazil, between April 1996 and February 1997.

pointed out by BEYsT et al. (2001) one must be careful when comparing sites since survey duration and depth have been recognised as confounding factors in such comparisons.

A relevant aspect of our results is the low numbers of benthic species. The presence of only one flatfish species and the complete absence of bathoids is perhaps unexpected when both flatfish species and skates are commonly caught and observed on sandy shores of Santa Catarina (J. P. BARREIROs, pers. obs.). The collection method is probably responsible for this fact since these fish are able to bury themselves in sand and thus evade capture. This fact can also explain the low numbers of Synodus foetens. As stated by KUIPERs et al. (1992), the catch density and the species richness will be a function of their distribution with depth and substratum type, their ability to avoid the gear and the mesh-size selectivity. Net efficiency and shoaling behaviour can increase the difficulty of interpreting the data (GIBSON et al., 1993; LYONS, 1986; PIERCE et al., 1990).

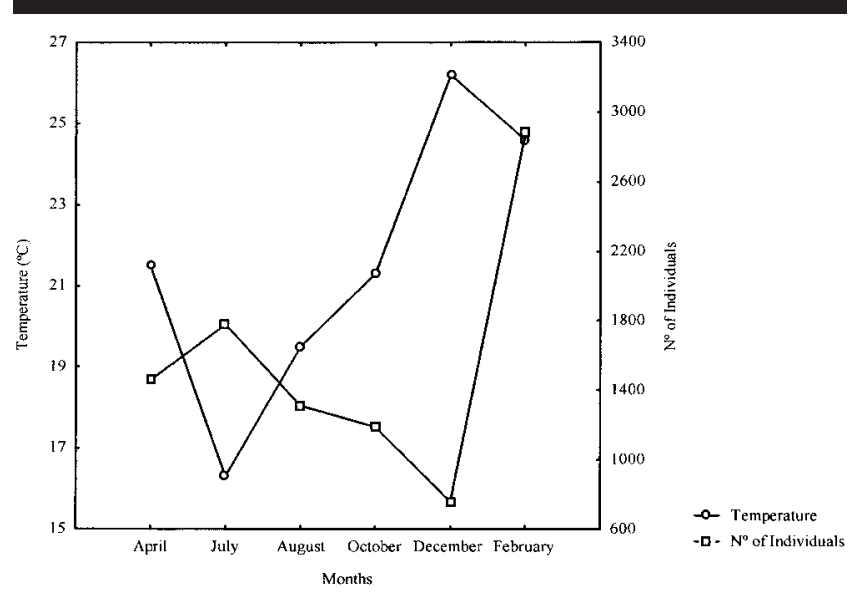

Figure 3. Number of individuals and temperature in Canto Grande, SC, Brazil, between April 1996 and February 1997.

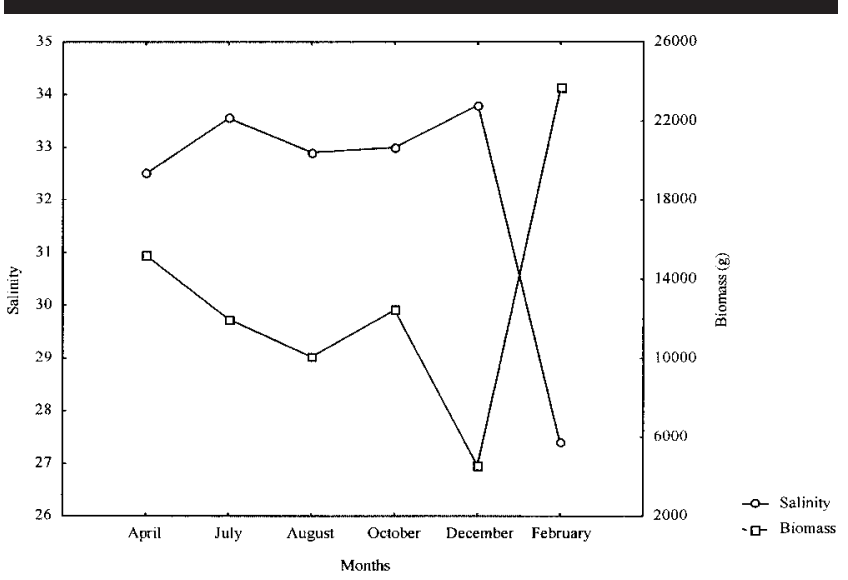

Figure 4. Total biomass and salinity in Canto Grande, SC, Brazil, between April 1996 and February 1997.

As noted by SANTOS and NASH (1995), unstressed fish assemblages should show a high species diversity with low similarities in species composition between seasons. The aggregation of CG has a low diversity but still has low similarities between samples. Human-induced pollution and high levels of anthropogenic activity may be the main cause for this situation although there is no data available to support this assumption.

The major changes in the species compositions in CG were due to: i) a decrease in the numbers of Atherinella brasiliensis from April to July, probably related to a decrease in water temperature which this species avoids (CERVIGón et al., 1992) and an increase of Lycengraulis grossidens in July when this species migrates from estuaries to the sea (WHITEHEAD et al., 1988); ii) July was also the month in which great numbers of Pomatomus saltator occurred, due to their characteristic winter migrations (see HARE and COWEN, 1993, 1996; JUANES and CONOVER, 1995); iii) the great abundance of Brevoortia pectinata in October, probably related to the beginning of its breeding season and consequent aggregation in shallow waters (see WHITEHEAD, 1985) and iv) the massive occurrence of Anchoviella lepidontostole, Cetengraulis edentulus and Sardinella brasiliensis in February, together with a great increase in the numbers of Trichiurus lepturus. The first three species are known to prefer warmer waters thus explaining their occurrence in summer (WHITEHEAD et al., 1988). On the other hand, it is known that juveniles and

Table 4. Differences in biomass between monthly samples from Canto Grande, SC, Brazil (g $1000 \mathrm{~m}^{-2}$ ) between April 1996 and February 1997.

\begin{tabular}{lccc}
\hline \hline Months & t-Value & $P$ & $P$ Variances \\
\hline April & 2.041 & $>0.05$ & 0.689 \\
July & 2.440 & 0.040 & 0.954 \\
August & 2.729 & 0.025 & 0.720 \\
October & 2.404 & 0.042 & 1.000 \\
December & 3.515 & 0.007 & 0.124 \\
February & 1.159 & $>0.05$ & 0.229 \\
\hline
\end{tabular}




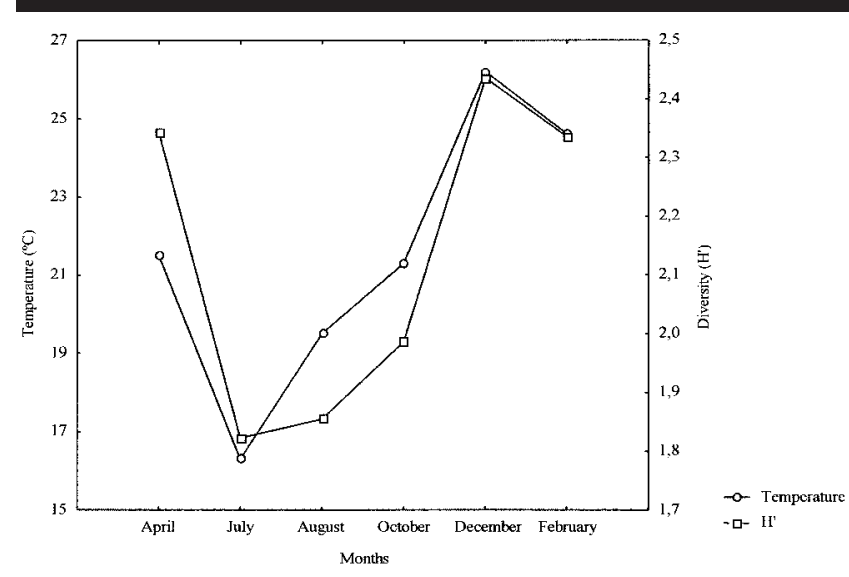

Figure 5. Diversity $\left(H^{\prime}\right)$ and temperature in Canto Grande, SC, Brazil, between April 1996 and February 1997.

small adults of T. lepturus make nocturnal migrations to shallow waters whenever these are warm (MEYER and SMALE, 1991). In Canto Grande, as in most shallow water fish communities, a few species are dominant both in terms of numbers and biomass (ALLEN and HoRN, 1975).

Nearby rocky shores apparently do not recruit fish to this sandy beach. None of the rocky shore's common species (e.g. Epinephelus marginatus, Mycteroperca acutirostris, Abudefduf saxatilis, Bathygobius soporator and many Blennidae species) were either present or were common in Canto Grande. As seen, the community is dominated by small pelagic species that use the area as a foraging ground and, for some cases, may recruit to the area for reproduction purposes (e.g. Cetengraulis grossidens, Anchoviella lepidontostole) (BARREIROs et al., unpublished results).

In conclusion, the fish community of CG is characterised by strong seasonality in which greater abundances, biomass, richness and diversity are found in summer months as normally found in other temperate to subtropical environments.

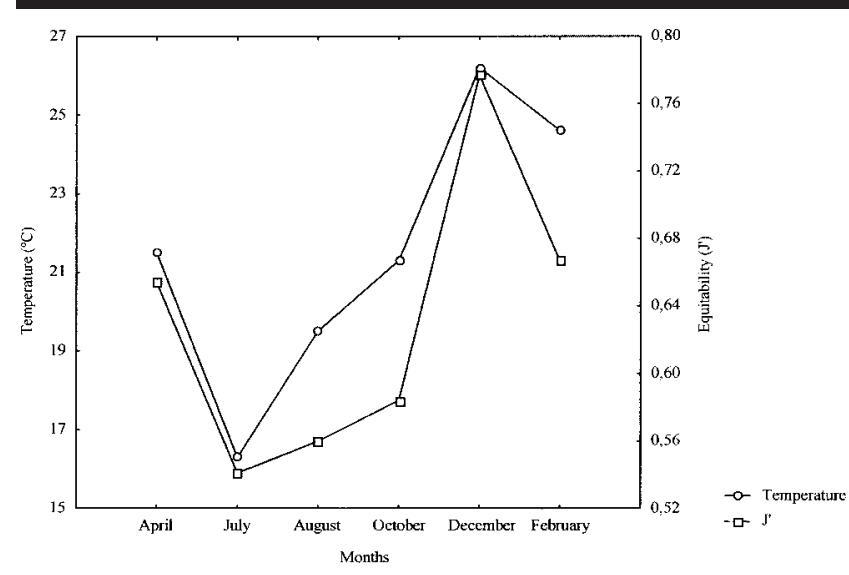

Figure 6. Equitability $\left(J^{\prime}\right)$ and temperature in Canto Grande, SC, Brazil, between April 1996 and February 1997.

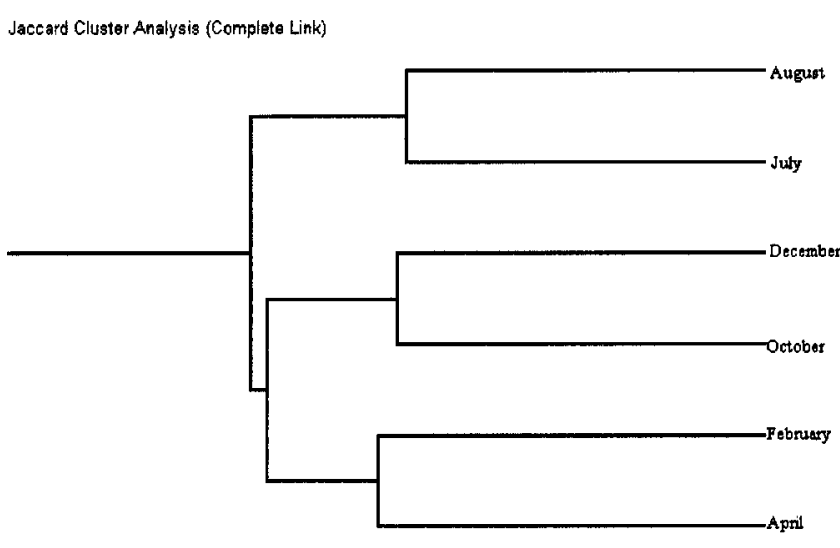

$0, \%$ Similarity

50 .

100

Figure 7. Percent similarity (Jaccard coefficient) between samples from Canto Grande, SC, Brazil (April 1996 to February 1997).

The community is dominated by pelagic and gregarious species and the presence of true residents is small but probably underestimated.

Further studies are needed in order to have a better understanding of soft sediment shallow areas in Santa Catarina, especially their nursery function. The intensive use of the littoral areas, especially of sheltered beaches such as Canto Grande may affect fish communities in many ways.

\section{ACKNOWLEDGMENTS}

Thanks are due to the students and technicians of the Universidade do Vale do Itajaí who made collections possible: Aluizio Caffé, Áthila Andrade, Fábio Lopes, Leonardo Machado, Norberto Ghizoni, and Valdenir Inez. Fernando L. Diehl and Alfredo Borba were always supportive and helpful. Travels and stays of JPB in Brazil were supported by the Programa PRODEP, Medida 5-Acção 5.2, Concurso Público no 1/PRODEP/96 and by kind courtesy of the CTTMar/UNIVALI. Comments and suggestions from Ivan Sazima and Paulo Borges greatly improved previous versions of the ms. Thanks are also due to the anonymous referee and to A. H. L. Huiskes for their valuable contributions.

Table 5. Berger-Parker index (d) and inverse (1/d) for the samples taken in Canto Grande, SC, Brazil.

\begin{tabular}{lcc}
\hline \hline Months & $\mathrm{d}$ & $1 / \mathrm{d}$ \\
\hline April & 0.347 & 2.882 \\
July & 0.405 & 2.469 \\
August & 0.330 & 3.030 \\
October & 0.448 & 2.232 \\
December & 0.185 & 5.405 \\
February & 0.153 & 6.536 \\
\hline
\end{tabular}




\section{LITERATURE CITED}

Allen, L. J. and HorN, M. H., 1975. Abundance, diversity and seasonality of fishes in Colorado Lagoon, Alamitoos Bay, California. Estuarine, Coastal and Marine Science, 3, 371-380.

Ali, T. S. and Hussain, N. A., 1990. Composition and seasonal fluctuations of intertidal fish assemblage in Kohr al-Zubair, Northwestern Arabian Gulf. Journal of Applied Ichthyology, 6, 24-36.

Araújo, F. G. and Costa de Azevedo, M. C., 2001. Assemblages of southeast-south Brazilian coastal systems on the distribution of fishes. Estuarine, Coastal and Shelf Science, 52, 729-738.

BennetT, B. A., 1989. The fish community of a moderately exposed beach on the sowthwestern Cape coast of South Africa and an assessment of this habitat as a nursery for juvenile fish. Estuarine, Coastal and Shelf Science, 28(6), 293-305.

Berger, W. H. and PARker, F. L., 1970. Diversity of planctonic Foraminifera in deep-sea sediments. Science, 168, 1345-1347.

Beyst, B.; Hostens, K., and Mees, J., 2001. Factors influencing fish and macrocrustacean communities in the surf zone of sandy beaches in Belgium: temporal variation. Journal of Sea Research, 46: 281-294.

Black, R. and Miller, R. J., 1991. Use of intertidal zone by fish in Nova Scotia. Environmental Biology of Fishes, 31, 109-121.

Brown, A. C. and McLachlan, A., 1990. Ecology of Sandy Shores. Elsevier, Amsterdam, Netherlands. xii $+328 \mathrm{pp}$.

CAstro, A. C. L., 1999. Diversidade da assembléia depeixes em Igarapés do Estuário do Rio Paciência-MA, p. 633. In: EnConTro BRAsileiro DE ICtiologia (13: 1999: São Carlos). Resumos. São Carlos: Universidade Federal de São Carlos, 1999. 671pp.

Cervigón, F. R.; Cipriani, R.; Fisher, W.; Garibaldi, L.; HenDrickx, M.; Lemus, A. J.; Márquez, R.; Poutiers, J. M.; RoBAINA, G., and RoDRIGUEz, B., 1992. Fichas FAO de identificación de espécies para los fines de la pesca. Guia de campo de las espécies comerciales marinas y de águas salobres de la costa septentrional de Sur America. FAO, Rome. 513pp.

Clark, B. M.; Benneth, B. A., and Lambert, S. J., 1996. Temporal variations in surf zone fish assemblages from False Bay, South Africa. Marine Ecology Progress Series, 131, 35-47.

Gibson, R. N., 1999. Movement and homing in intertidal fishes. In: Horn, M. H.; Martin, K. L. M., and ChOtKowski, M. A. (Eds.) Intertidal Fishes: Life in Two Worlds. Academic Press, London, pp. $97-125$.

Gibson, R. N. and Ezzi I. A., 1987. Feeding relationships of a demersal fish assemblage on the west coast of Scotland. Journal of Fish Biology, 31, 55-69.

Gibson, R. N. and Yoshiyama, R. M., 1999. Intertidal fish communities. In: HorN, M. H.; Martin, K. L. M., and ChotKowski, M. A. (Eds.). Intertidal Fishes: Life in Two Worlds. Academic Press, London, pp. 264-296.

Gibson, R. N.; Ansell, A. D., and RobB, L., 1993. Seasonal and annual variations in abundance and species composition of fish and macrocrustacean communities on a Scottish sandy beach. $M a$ rine Ecology Progress Series, 98, 89-105.

HARE, J. A. and Cowen, R. K., 1993. Ecological and evolutionary implications of the larval transport and reproductive strategy of bluefish Pomatomus saltatrix. Marine Ecology Progress Series, 98(1-2), 1-16.

HaRE, J. A. and Cowen, R. K., 1996. Transport mechanisms of larval and pelagic juvenile bluefish (Pomatomus saltatrix) from the South Atlantic Bight spawning grounds to Middle Atlantic Bight nursery habitats. Limnology and Oceanography, 41(6), 1264-1280.

Hook, J. H., 1991. Seasonal variation in relative abundance and species diversity of fishes in South Bay. Contributions in Marine Science, 32, 127-141.

JuAnes, F. and Conover, D. O., 1995. Size-structured piscivory. Advection and the linkage between predator and prey recruitment in young-of-the-year bluefish. Marine Ecology Progress Series, 128(1-3), 287-304.

Kubecka, J. and Bohm, M., 1991. The fish fauna of the Jordan reservoir, one of the oldest man-made lakes in Central Europe. Journal of Fish Biology, 38, 935-950.

Kuipers, B. R.; Maccurrin, B.; Miller, J. M.; VAN Der Veer, H. W., and WitTE, J. IJ., 1992. Small trawls in juvenile flatfish research: their development and efficiency. Netherlands Journal of Sea Research, 29, 109-117.

Lazzari, M. A.; Sherman, S.; Brown, C. S.; King, J.; Joule, B. J.; Chenoweth, S. B., and Langton, R. W., 1999. Seasonal and annual variations in abundance and species composition of two nearshore fish communities in Maine. Estuaries, 22(3A), 636-647.

Ludwig, J. A. and ReYnolds, J. F., 1988. Statistical Ecology-A Primer on Methods and Computing. John Wiley \& Sons, N.Y. xvii $+337 \mathrm{pp}$.

Lyons, J., 1986. Capture efficiency of a beach-seine for seven freshwater fishes in a north temperate lake. North American Journal of Fish Management, 6, 288-289.

MagurRan, A. E., 1988. Ecological Diversity and its Measurement. Croom Helm, Australia. x $+179 p$.

McErlean, A. J.; O'Connor, S. G.; Milhursky, J. A., and Gibson, C. I., 1973. Abundance, diversity and seasonal patterns of estuarine fish populations. Estuarine, Coastal and Shelf Science, 15, $485-495$.

Meyer, M. and Smale, M. J., 1991. Predation patterns of demersal teleosts from the Cape south and west coasts of South Africa. 1. Pelagic predators. South African Journal of Marine Sciences, 11, 173-191.

NASH, R. D. M., 1988. The effects of disturbance and severe seasonal fluctuations in environmental conditions on north temperate shallow-water fish assemblages. Estuarine, Coastal and Shelf Science, $26,123-135$

Nash, R. D. M. and SAntos, R. S., 1998. Seasonality in diel catch rate of small fishes in a shallow-water fish assemblage at Porto Pim Bay, Faial, Azores. Estuarine, Coastal and Shelf Science, 47, 319-328.

Pessanha, A. L. M.; AraúJo, F. G.; Azevedo, M. C. A., and Gomes, I. D., 1999. Variações espaciais e temporais na composição e estrutura da comunidade de peixes jovens da Baía de Sepetiba, RJ, p. 632. In: EnContro Brasileiro DE ICTIOLOGIA (13: 1999: São Carlos). Resumos. São Carlos: Universidade Federal de São Carlos, 1999. 671pp.

Pielou, E. C., 1977. Mathematical Ecology. Wiley, N.Y.

Pierce, C. L.; Rasmussen, J. B., and LegGett, W. C., 1990. Sampling littoral fish with a seine: corrections for variable catch efficiency. Canadian Journal of Fisheries and Aquatic Sciences, 47, 1004-1010.

Roque, C. P. and Kuroshima, K. N., 2000. Avaliação dos traços de metais nos mexilhões cultivados em Canto Grande, Armação e São Francisco do Sul (Santa Catarina), p. 268-269. In: XIII SEMANA NaCional DE OCEANografia. Anais-Proceedings. Centro de Ciências Tecnológicas da Terra e do Mar, Universidade do Vale do Itajaí, Itajaí, Santa Catarina, Brasil. 671pp.

Ross, S. T.; McMichael, R. H., and Ruple, D. L., 1987. Seasonal and diel variations in the standing crop of fishes and macroinvertebrates from a Gulf of Mexico surf zone. Estuarine, Coastal and Shelf Science, 25, 391-412.

SAntos, R. S. and NASH, R. D. M., 1995. Seasonal changes in a sandy beach fish assemblage at Porto Pim, Faial, Azores. Estuarine, Coastal and Shelf Science, 41, 579-591.

SchetTini, C. A. F., 1997. Impactos ambientais associados ao cultivo de moluscos marinhos, p. 551-555. In: X SEMANA NACIIONAL DE OCEANOGRAFIA e VII ENCONTRO BRASILEIRO DE OCEAN'OGRAFOS. Anais-Proceedings. Faculdade de Ciências do Mar, Universidade do Vale do Itajaí, Itajaí, Santa Catarina, Brasil. 579pp.

SEGE, 1991. Atlas Escolar de Santa Catarina. Secretaria de Estado de Coordenação Geral e Planejamento (SEPLAN/SC) e Subsecretaria de Estudos Geográficos e Estatísticos. Florianópolis.

VARGAS, M. and SiElfEld, W., 1997. Playa Chipana (21 degree 19' S, 70 degree $04^{\prime} \mathrm{W}$ ): A nursery and smelting area for marine coastal fish in northern Chile. Archives of Fisheries and Marine Research, 45(2), 167-182. 
WhiteheAd, P. J. P., 1985. In: FAO species catalogue. Clupeoid fishes of the world (Suborder Clupeoidei). An annotated and illustrated catalogue of the herrings, sardines, pilchards, sprats, shads, anchovies and wolf-herrings. Part 1-Chirocentridae, Clupeidae and Pristigastridae. FAO Fisheries Synopsis, 7(125), part 1, 303pp.

Whitehead, P. J. P.; Nelson, G. J., and Wrongatana, T., 1988. In: FAO species catalogue. Clupeoid fishes of the world (Suborder
Clupeoidei). An annotated and illustrated catalogue of the her rings, sardines, pilchards, sprats, shads, anchovies and wolf-herrings. Part 2-Engraulidae. FAO Fisheries Synopsis, 7(125), part 2, 579pp.

WRIGHT, J. M., 1988. Seasonal and spatial differences in the fish assemblage of the non-estuarine Sulaibikhat Bay, Kuwait. Marine Biology, 102, 135-142.

$\square$ RESUMO $\square$

Neste trabalho realizaram-se amostragens, com uma rede de praia, de modo a estudar a comunidade de peixes de substrato arenoso na enseada de Canto Grande, Santa Catarina, Brasil. As amostragens realizaram-se em intervalos de 3 horas durante períodos de 24 h, numa base bimensal, entre Abril de 1996 e Fevereiro de 1997. Verificou-se existir uma variação sazonal no número de espécies, densidade de peixes e biomassa, tendo os valores mais elevados ocorrido em Fevereiro (38 espécies, 257.6 peixes $1000 \mathrm{~m}^{-2}, 2286.4 \mathrm{~g} 1000 \mathrm{~m}^{-2}$ ). Recolheu-se um total de 67 espécies, pertencentes a 56 géneros e a 33 famílias, sendo a comunidade dominada por sete espécies pertencentes a três famílias: Atherinella brasiliensis (Atherinidae); Brevoortia pectinata, Harengula clupeola e Sardinella brasiliensis (Clupeidae); Anchoviella lepidontostole, Cetengraulis edentulus e Lycengraulis grossidens (Engraulidae). Tanto a diversidade de espécies $\left(H^{\prime}\right)$ como a equitabilidade $\left(J^{\prime}\right)$ foram médias a elevadas ao longo do ano devido à baixa dominância. A maior mudança na estrutura da comunidade ocorreu entre os meses de Inverno (Julho e Agosto) e as outras estações. Nenhuma das espécies dominantes pode ser classificada como residente. Os principais predadores foram Pomatomus saltator (Inverno) e Trichiurus lepturus (Verão). A maior parte das espécies observadas foram ou peixes juvenis ou espécies pelágicas de pequeno tamanho e fortemente gregárias.

PALAVRAS CHAVE: Agregação de peixes, variações sazonais, praias arenosas, Santa Catarina, sul do Brasil. 